\title{
Correlates of exposure to second-hand smoke in an urban Mediterranean population
} Jorge Twose $e^{1,2,3}$, Anna Schiaffino ${ }^{1}$, Montse García ${ }^{1}$, Josep Maria Borras ${ }^{1,4}$ and Esteve Fernández*1,2

Address: ${ }^{1}$ Cancer Prevention and Control Unit, Institut Català d'Oncologia, Institut d'Investigació Biomèdica de Bellvitge (IDIBELL), Spain, 2Department of Experimental and Health Sciences, Universitat Pompeu Fabra, Spain, ${ }^{3}$ Organització Catalana de Transplantaments and ${ }^{4}$ Department of Clinical Sciences, Universitat de Barcelona, Spain

Email: Jorge Twose - jtwose@catsalut.net; Anna Schiaffino - aschiaffino@iconcologia.net; Montse García - mgarciam@iconcologia.net; Josep Maria Borras - jmborras@ico.scs.es; Esteve Fernández* - efernandez@ico.scs.es

* Corresponding author

Published: 5 August 2007

BMC Public Health 2007, 7:194 doi:10.1 186/147|-2458-7-194
Received: II December 2006

Accepted: 5 August 2007

This article is available from: http://www.biomedcentral.com/I47I-2458/7//94

(c) 2007 Twose et al; licensee BioMed Central Ltd.

This is an Open Access article distributed under the terms of the Creative Commons Attribution License (http://creativecommons.org/licenses/by/2.0), which permits unrestricted use, distribution, and reproduction in any medium, provided the original work is properly cited.

\begin{abstract}
Background: To describe the socio-demographic factors associated with exposure to secondhand smoke (SHS) in different settings (home, leisure, and workplace).

Methods: We analysed cross-sectional data on self-reported SHS exposure in 1059 non-daily smokers interviewed in the Cornellà Health Interview Survey Follow-up Study in 2002. We calculated age-adjusted prevalence rates and prevalence rate ratios of SHS exposure at home, at the workplace, during leisure time, and in any of these settings.

Results: The age-standardized prevalence rate of SHS exposure in any setting was $69.5 \%$ in men and $62.9 \%$ in women. Among men, $25.9 \%$ reported passive smoking at home, $55.1 \%$ during leisure time, and $34.0 \%$ at the workplace. Among women, prevalence rates in these settings were $34.1 \%$, $44.3 \%$ and $30.1 \%$, respectively. Overall exposure to SHS decreased with age in both men and women. In men, SHS exposure was related to marital status, physical activity, smoking, and alcohol intake. In women, SHS exposure was related to educational level, marital status, occupational status, self-perceived health, smoking-related illness, and alcohol intake.

Conclusion: The prevalence of SHS exposure in this population was high. The strongest association with exposure were found for age and occupational status in men, and age and educational level in women.
\end{abstract}

\section{Background}

The Surgeon General's report [1] in 1986 and the report of the US Environmental Protection Agency [2] (EPA) in 1992 defined passive smoking or second-hand smoke (SHS) as a health hazard. More recently, SHS has been classified as "carcinogenic to humans (Group 1)" by the International Agency for Research on Cancer [3]. Passive smoking is a proven cause of lung cancer as well as other tumours in non-smokers, and is also related to the development of respiratory diseases in children and adults, and to the appearance of cardiovascular diseases [2-4].

In Spain, where the smoking epidemic was delayed compared to other Western countries[5-9], exposure to SHS 
was not considered a public health concern until recently $[10,11]$. Smoking at the workplace and in public places was common and rarely restricted [12-14] until the introduction of a comprehensive anti-smoking law in January 2006. Thus, information on exposure to SHS in the Spanish population is scarce.

Although National Health Interview Surveys have been conducted since 1987, they have included no information on SHS exposure. In Spain the prevalence of exposure to SHS, estimated by self-reported information in an ad hoc respiratory survey [15] and local Health Interview Surveys (in the Barcelona area) $[16,17]$, was approximately $60 \%$. These early studies collected information on SHS exposure at home and at the workplace, but not during leisure time, a setting that may be a source of substantial exposure among young people $[2,18]$. Moreover, little is know about the associations between SHS exposure and sociodemographic characteristics, and both exposure patterns and determinants may be changing due to the implementation in January 2006 of an almost total ban on smoking in enclosed public places and workplaces in Spain $[19,20]$. We designed the present study [17] to determine the prevalence and determinants of SHS exposure in an urban Mediterranean population in Spain in 2002.

\section{Methods \\ Population}

The Cornellà Health Interview Survey Follow-up (CHIS.FU) Study is a prospective cohort study of a representative sample $(\mathrm{n}=2500,1263$ women and 1237 men $)$ of the non-institutionalized population of Cornellà de Llobregat, a city located in the metropolitan area of Barcelona, Catalonia (Spain) with a total population of 85061 inhabitants. The design of the CHIS.FU study was described elsewhere [21,22]. Inclusion of the participants in the cohort was based on the date of the interview for the Cornellà Health Interview Survey performed in 1994 (January to December) with face-to-face interviews [23]. In 2002, after record linkage with the municipal census to update vital status and contact information, active telephone follow-up was implemented [24], including a follow-up questionnaire with information on self-perceived health, lifestyles, other health-related variables, and exposure to SHS. Participants gave informed verbal consent to be included both in the 1994 and 2002 interview. All data were managed centrally at the Cancer Prevention and Control Unit of the Catalan Institute of Oncology, following the confidentiality rules for this type of data. The research ethics committee of the Hospital Universitari de Bellvitge/Institut d'Investigacions Biomèdiques de Bellvitge revised and provided ethical approval to the CHIS.FU study.
We obtained a $64.3 \%$ response rate in the total cohort: 1608 participants took part in the follow-up interview, with 1438 direct respondents and 170 proxy respondents who answered the questionnaire items on behalf of the index person when he or she was unable to respond because of health problems, or was $<15$ years old. There was a $5 \%$ refusal rate $(n=123)$, but 94 of these participants responded to a brief ad hoc questionnaire, and thus provided information on educational level, self-perceived health, and smoking behaviour, as well as the reason for declining to participate [21].

Among the 1608 participants interviewed in 2002, we selected those who answered questions about SHS exposure in the follow-up questionnaire. Questionnaires obtained from "proxy" respondents did not include the SHS exposure section of the questionnaire and were thus excluded. We also excluded 379 participants who identified themselves as daily smokers (people who smoked $\geq 1$ cigarette/day), since exposure to SHS is irrelevant, but we included those who identified themselves as occasional smokers (< 1 cigarette/day). The final sample analysed here consisted of 1059 participants (449 men and 610 women) aged $\geq 15$ years who were never, past or occasional smokers in 2002.

\section{Dependent variables}

The exposure variables were dichotomized as exposure or no exposure to SHS in each of the settings (home, leisure time and workplace, see Appendix). Subsequently a new variable was created: overall self-reported SHS exposure in any of the three settings. From the classification of participants according to the duration of exposure during leisure time, we obtained an approximate estimate of the intensity of exposure. Thus, participants who stated they were not exposed to SHS were coded as "None", those who stated they were exposed during $<1$ hour per day from Monday to Thursday or from Friday to Sunday were grouped in the "Low" intensity category; those who were exposed 1 to 4 hours per day were classified in the "Intermediate" intensity category, and participants who were exposed > 4 hours per day on any day of the week were classified int the "high" intensity category. The questionnaire items were derived from previous questionnaires [16] and are currently undergoing validation as part of an ongoing project [25].

\section{Independent variables}

We analysed the following socio-demographic variables: sex, age (15-24 years, 25-44 years, 45-64 years and $\geq 65$ years), educational level ( $\leq$ primary studies; secondary studies; and university studies), marital status (single, married, or divorced/widowed), and occupational status (employed, unemployed, disabled, retired, housewife, student, or other). We recoded self-perceived health as 
optimal (very good, good, or fairly good health) and suboptimal (fairly poor, poor or very poor health). Comorbidity was assessed with a list of 16 common chronic conditions and recoded as the absence or presence of any of them, and presence of smoking-related diseases (any of the following: heart disease, varicose veins, asthma, chronic bronchitis, stomach or duodenal ulcer, cerebrovascular disease) was treated as a dichotomous variable (presence or absence of any of these 6 types). We studied physical activity $[26,27]$ as occupational physical activity (inactive, light, moderate or intense) and as leisure physical activity (sedentary, moderate or intense). Smoking was recorded as occasional smoker, former smoker or never smoker; and alcohol intake was recorded as non-drinker, low risk ( $<6.87 \mathrm{~g} /$ day in men or $<2.75 \mathrm{~g} /$ day in women $)$, moderate risk (6.87-17.75 g/day in men or $2.75-8.06 \mathrm{~g} /$ day in women), or high risk (>17.75 g/day in men or > $8.06 \mathrm{~g} /$ day in women), according to terciles of consumption in each sex.

\section{Statistical analysis}

We calculated age-specific and age-standardized prevalence rates (and their 95\% confidence interval [CI]) of SHS exposure for men and women. Age-standardized prevalence rates were computed by the direct method, using the Cornellà de Llobregat population obtained from the 2001 municipal census as the referent population. We calculated the overall prevalence rate of SHS exposure and the prevalence rates of SHS in different settings, and used a diamond-shaped equiponderant graph [28] to represent the prevalence rates of SHS exposure according to setting in each age group. The plot projects three-dimensional bar graphs in two dimensions whereby the third dimension is replaced with a polygon whose area and middle vertical and horizontal lengths represent the prevalence (\%) of participants exposed to SHS.

To evaluate the associations between SHS exposure and different socio-demographic and lifestyle variables, we computed the prevalence rate ratios (PR) and their 95\% CI by transformation of the corresponding odds ratios obtained with unconditional logistic regression models [29-31]. Those variables significantly associated in the bivariate analyses were entered in multivariate models for each of the settings (home, leisure time, workplace and overall). All analyses were stratified by sex and adjusted for age.

\section{Results}

The age-standardized prevalence rate of self-reported exposure to SHS was $69.5 \%$ (95\% CI: $64.5 \%-74.4 \%$ ) in men and $62.9 \%$ (95\% CI: 58.1\%-67.6\%) in women [17]. The prevalence of exposure to SHS differed according to setting (Figure 1): $25.9 \%$ (95\% CI: $21.8 \%-30.1 \%$ ) of the men reported passive smoking at home, 55.1\% (95\% CI:
$50.8 \%-59.4 \%)$ during leisure time, and 34.0\% (95\% CI: $23.5 \%-45.6 \%)$ at the workplace. In women the prevalence rates for the different settings were 34.1\% (95\% CI: $29.8 \%-38.5 \%$ ), $44.3 \%$ (95\% CI: $40.5 \%-48.2 \%$ ), and $30.1 \%$ (95\% CI: $18.9 \%-41.3 \%)$, respectively. In both men and women overall self-reported SHS exposure tended to decrease with age, with a significant linear trend $\left(\chi^{2}=108.9, P<0.01\right.$, in men; and $\chi^{2}=126.8, P<0.01$, in women, Figure 1). This pattern was also present for SHS exposure during leisure time in men $\left(\chi^{2}=102.9, P<0.01\right)$ and women $\left(\chi^{2}=163.2, P<0.01\right)$, but was less apparent for exposure to SHS at home and at the workplace [17].

The prevalence of high-intensity SHS exposure (more than 4 hours weekly) during leisure time was higher in young people (29.4\% in men and $31.5 \%$ in women) and decreased to $0.8 \%$ in men and $0.6 \%$ in women older than 64 years (Figure 2).

The prevalence rate ratios (PR) of exposure to SHS adjusted for age, according to socio-demographic and lifestyle variables, are shown in Table 1 for men and in Table 2 for women. In Tables 3 and 4 we show the results of multivariate analyses for variables that were found to be associated in the bivariate analysis. In men, SHS exposure was associated with occupational physical activity $(\mathrm{PR}=$ 1.35; 95\% CI: $1.05-1.74$ for those who stated being physically active vs. those who were inactive, Table 3). In women, the prevalence of SHS exposure at home was lower among housewives than women employed outside the home (PR $=0.85 ; 95 \% \mathrm{CI}: 0.72-1.00)$. Self-reported SHS exposure was higher among women who had any of the six smoking-related diseases $(\mathrm{PR}=1.16 ; 95 \% \mathrm{CI}$ : 1.02-1.33) (Table 4). In men, SHS exposure during leisure time was related to marital status (lower prevalence in single vs. married men, $\mathrm{PR}=0.46$; $95 \% \mathrm{CI}$ : 0.31-0.68), and to high alcohol consumption (PR $=1.40 ; 95 \%$ CI: $1.09-1.81$ vs. non-drinkers) (Table 3 ). In women, SHS exposure was less prevalent in married $(\mathrm{PR}=0.59 ; 95 \%$

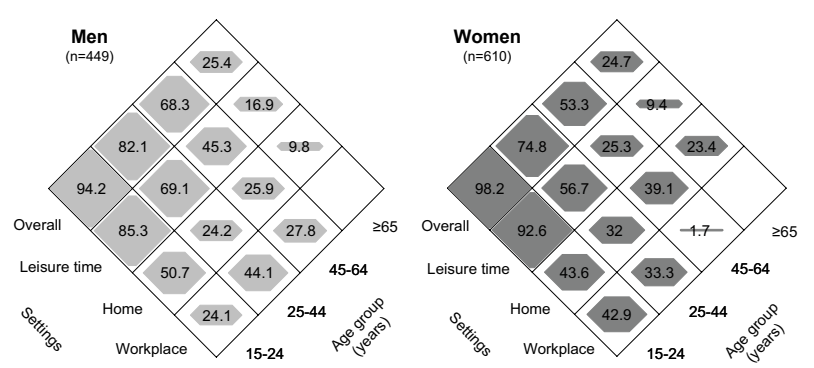

Figure I

Prevalence (\%) of exposure to second-hand smoke among men and women by age group and setting. Cornellà, Spain, 2002. 


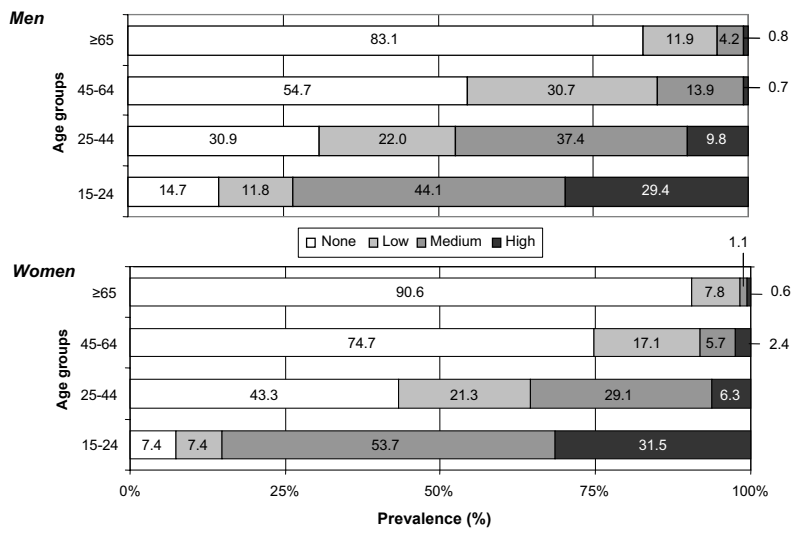

Figure 2

Intensity of exposure (\%) to second-hand smoke among men and women during leisure time by age group. Cornellà, Spain, 2002.

CI: 0.44-0.78) and divorced or widowed women (PR = 0.75 ; 95\% CI: 0.59-0.95) vs. single women. Exposure to SHS was inversely associated with suboptimal self-perceived health ( $\mathrm{PR}=0.87 ; 95 \% \mathrm{CI}: 0.78-0.96)$ and directly related to moderate or high alcohol intake vs. non-drinkers (Table 4). In men, exposure to SHS at the workplace was associated with occupational physical activity (Table $3)$. In women, SHS exposure at the workplace was more frequent in those with a university-level education (PR = 1.47; 95\% CI: $1.05-2.07$ vs. no university education or primary education) and with low alcohol intake (Table 4). Overall SHS exposure in any of the settings was associated in men with being married and being an occasional smoker, whereas in women it was associated with being divorced or widowed, and with no employment outside the home (Tables 3 and 4).

\section{Discussion}

The results of this study show that more than half of the people in the sample were exposed to SHS in 2002. This proportion of passive smokers was similar in both sexes. Previous studies from the same period have found a similar prevalence of SHS exposure in Spain [32,33], although exposure may have changed, especially at the workplaces, after 2006 with the implementation of the new anti-smoking law [34]. Notably, more than $90 \%$ of young people (15-24 years old) were exposed to SHS, and approximately $30 \%$ of young people reported high levels of exposure.

Our study shows that age was the main determinant of self-reported exposure to SHS: we found a statistically significant inverse association between age and exposure to SHS. Once age was controlled for, marital status was the other main determinant of overall exposure to SHS (single people were more likely to be passive smokers). The association between overall SHS exposure and marital status may be explained by the fact that single persons spend more of their leisure time in places like bars, restaurants or discos, where there were no restrictions on smoking in 2002, (when this study conducted), and where levels of second-hand smoke were likely to be high [35-37].

Other socio-demographic variables such as educational level or occupational status were associated with exposure to SHS at home and at the workplace in women. Educational level among young people was inversely associated with exposure to SHS among women, and directly associated with exposure among men, which is in agreement with current data on smoking prevalence in Spain [38]. In women, we found modest associations between SHS exposure and different health-related variables. Participants who perceived their health as optimal had high leisure-time SHS exposures. It is reasonable to think that healthy people are more likely to spend their leisure time at hospitality venues. However, women who had smoking-related diseases presented a high prevalence of SHS exposure at home. A possible explanation is that these women live with smokers (a factor not investigated in this study), which could lead to high exposures to SHS and thus make smoking-related illnesses more likely. However, the cross-sectional design of the study does not allow us to establish any causal connection.

Occupational physical activity was directly associated with SHS exposure in men at home and at the workplace. Those participants whose job required intense physical effort may work in settings where smoking is frequent, such as the manufacturing or construction sectors [27], so they might work near smokers [39]. In addition, participants from lower social classes, in which the prevalence of active smoking is higher [38,40-42], are more likely to have jobs involving intense physical activity. Previous studies have shown a similar socio-economic gradient in SHS exposure $[43,44]$. Occasional smoking was also associated with SHS exposure in men, possibly because they interacted with smokers or often went to places where exposure to tobacco smoke was high. Finally, alcohol consumption in both men and women was also associated with SHS exposure, possibly because in 2002 there were no restrictions on smoking in places where alcohol consumption is usual in Spain (mainly bars and restaurants. i.e., enclosed areas where ventilation is less than optimum).

The results of this study show that the prevalence of SHS exposure was high at workplaces and during leisure time in 2002, and that this especially affected young and middle-aged people. This leisure environment is at the same time the workplace for many other people, e.g., employ- 
Table I: Age-adjusted prevalence rate ratios (PR) and $95 \%$ confidence intervals $(\mathrm{Cl})$ of exposure to second-hand smoke in different settings according to socio-demographic variables in men. Cornellà, Spain, 2002.

\begin{tabular}{|c|c|c|c|c|}
\hline & Home PR $(95 \% \mathrm{Cl})$ & Leisure time PR $(95 \% \mathrm{Cl})$ & Workplace PR $(95 \% \mathrm{Cl})$ & Overall PR $(95 \% \mathrm{Cl})$ \\
\hline \multicolumn{5}{|l|}{ Educational level } \\
\hline \multicolumn{5}{|l|}{$\leq$ Primary studies } \\
\hline Secondary studies & $0.98(0.77-1.25)$ & $1.07(0.73-1.55)$ & $1.05(0.83-1.34)$ & $0.87(0.53-1.43)$ \\
\hline University studies & $1.05(0.85-1.31)$ & $1.00(0.61-1.63)$ & $0.88(0.64-1.22)$ & $1.40(0.65-3.01)$ \\
\hline \multicolumn{5}{|l|}{ Marital status } \\
\hline Single & 1 & 1 & 1 & I \\
\hline Married & $0.92(0.78-1.09)$ & $0.49(0.34-0.7 I)$ & $0.92(0.7 I-1.19)$ & $0.49(0.28-0.85)$ \\
\hline Widowed/Divorced & $0.91(0.69-1.19)$ & $0.63(0.37-1.05)$ & $1.03(0.48-2.20)$ & $0.52(0.27-0.99)$ \\
\hline \multicolumn{5}{|l|}{ Occupational status } \\
\hline Employed & 1 & 1 & - & 1 \\
\hline Unemployed & I. $18(0.82-|.7|)$ & $1.10(0.55-2.18)$ & - & $0.66(0.28-1.57)$ \\
\hline Disabled & $0.97(0.76-1.23)$ & $1.06(0.71-1.59)$ & - & $0.84(0.46-1.55)$ \\
\hline Retired & $0.93(0.8 \mathrm{I}-1.08)$ & $0.94(0.77-1.14)$ & - & $0.76(0.55-1.05)$ \\
\hline Student & $1.10(0.72-1.67)$ & $0.66(0.25-1.73)$ & - & $0.80(0.18-3.49)$ \\
\hline Other & $0.90(0.46-1.75)$ & $0.85(0.26-2.73)$ & - & $0.38(0.09-1.62)$ \\
\hline \multicolumn{5}{|l|}{ Self-perceived health } \\
\hline Optimal & 1 & 1 & 1 & I \\
\hline Suboptimal & $1.02(0.87-1.19)$ & $0.97(0.78-1.22)$ & $1.06(0.67-1.68)$ & $0.89(0.64-1.23)$ \\
\hline \multicolumn{5}{|l|}{ Comorbidity* } \\
\hline No & 1 & 1 & 1 & 1 \\
\hline Yes & $0.99(0.89-1.10)$ & $1.15(0.95-1.40)$ & $0.94(0.77-1.15)$ & $1.05(0.79-1.40)$ \\
\hline \multicolumn{5}{|l|}{$\begin{array}{l}\text { Smoking-related } \\
\text { diseases** }\end{array}$} \\
\hline No & 1 & 1 & 1 & 1 \\
\hline Yes & $1.00(0.90-1.11)$ & $0.87(0.73-1.05)$ & 0.91 (0.74-I.13) & $0.83(0.64-1.08)$ \\
\hline \multicolumn{5}{|l|}{$\begin{array}{l}\text { Occupational physical } \\
\text { activity }\end{array}$} \\
\hline Inactive & I & 1 & 1 & I \\
\hline Light & I.I7 (0.94-I.47) & $1.24(0.77-2.00)$ & $1.47(1.05-2.07)$ & $1.80(0.86-3.74)$ \\
\hline Moderate & $1.06(0.94-1.19)$ & $1.16(0.93-1.45)$ & $1.08(0.88-1.33)$ & $1.29(0.94-1.76)$ \\
\hline Intense & $1.35(1.05-1.74)$ & $1.16(0.71-1.89)$ & $1.45(1.04-2.01)$ & $2.02(0.90-4.55)$ \\
\hline \multicolumn{5}{|c|}{ Leisure physical activity } \\
\hline Sedentary & 1 & 1 & 1 & 1 \\
\hline Moderate & $0.92(0.74-1.15)$ & $1.32(0.94-1.85)$ & $0.72(0.47-I .1 \mathrm{I})$ & $1.12(0.65-1.91)$ \\
\hline Intense & $0.94(0.68-1.31)$ & $1.66(0.95-2.89)$ & $0.79(0.48-1.31)$ & $1.47(0.66-3.28)$ \\
\hline \multicolumn{5}{|l|}{ Smoking habit } \\
\hline Never smoker & I & 1 & 1 & I \\
\hline Occasional smoker & $0.99(0.78-1.26)$ & $1.82(0.98-3.39)$ & $1.08(0.74-1.58)$ & $3.56(1.19-10.67)$ \\
\hline Former smoker & $0.99(0.89-1.11)$ & $0.96(0.80-1.16)$ & $0.87(0.71-1.07)$ & $0.86(0.65-1.14)$ \\
\hline \multicolumn{5}{|l|}{ Alcohol intake ${ }^{* * *}$} \\
\hline Non-drinker & I & 1 & I & 1 \\
\hline Low risk & $0.90(0.76-1.05)$ & $1.19(0.86-1.64)$ & $1.06(0.81-1.40)$ & $0.99(0.63-1.54)$ \\
\hline Moderate risk & $1.03(0.89-1.20)$ & $1.20(0.94-1.55)$ & $0.99(0.78-1.26)$ & $1.36(0.93-1.99)$ \\
\hline High risk & $1.06(0.91-1.24)$ & $1.36(1.05-1.76)$ & I.05 (0.78-I.4I) & $1.28(0.89-1.86)$ \\
\hline
\end{tabular}

*Absence or presence of chronic diseases

**Absence or presence of smoking-related disease (heart diseases, high blood pressure, varicose veins, asthma or chronic bronchitis, stomach or duodenal ulcer, and cerebrovascular disease).

***Non-drinkers ( $0 \mathrm{~g} /$ day), low risk (< $6.87 \mathrm{~g} /$ day), moderate risk (6.87-17.75 g/day) and high risk (> $17.75 \mathrm{~g} /$ day) 
Table 2: Age-adjusted prevalence rate ratios (PR) and $95 \%$ confidence intervals $(\mathrm{Cl})$ of exposure to second-hand smoke in different settings according to socio-demographic variables in women. Cornellà, Spain, 2002.

\begin{tabular}{|c|c|c|c|c|}
\hline & Home PR $(95 \% \mathrm{Cl})$ & Leisure time PR $(95 \% \mathrm{Cl})$ & Workplace PR $(95 \% \mathrm{Cl})$ & Overall PR $(95 \% \mathrm{Cl})$ \\
\hline \multicolumn{5}{|l|}{ Educational level } \\
\hline \multicolumn{5}{|l|}{$\leq$ Primary studies } \\
\hline Secondary studies & $0.83(0.66-1.05)$ & $1.37(0.94-2.01)$ & $1.14(0.92-1.43)$ & $1.00(0.59-1.68)$ \\
\hline University studies & $0.80(0.60-1.06)$ & $2.44(1.40-4.22)$ & $1.51(1.10-2.08)$ & 6.01 (1.66-21.07) \\
\hline \multicolumn{5}{|l|}{ Marital status } \\
\hline Single & 1 & 1 & 1 & 1 \\
\hline Married & $0.91(0.72-1.15)$ & $0.53(0.4 \mathrm{I}-0.70)$ & $0.93(0.75-1.16)$ & $0.59(0.39-0.91)$ \\
\hline Widowed/Divorced & $1.04(0.75-1.42)$ & $0.68(0.54-0.86)$ & $0.94(0.70-1.27)$ & $0.58(0.4 \mathrm{I}-0.82)$ \\
\hline \multicolumn{5}{|l|}{ Occupational status } \\
\hline Employed & 1 & 1 & - & 1 \\
\hline Unemployed & $0.99(0.69-1.43)$ & $1.19(0.68-2.08)$ & - & $1.22(0.49-3.02)$ \\
\hline Disabled & $0.90(0.53-1.52)$ & $0.76(0.52-1.10)$ & - & $0.57(0.31-1.05)$ \\
\hline Retired & $0.98(0.78-1.23)$ & $1.00(0.88-1.13)$ & - & $0.83(0.64-1.07)$ \\
\hline Housewife & $0.84(0.72-0.99)$ & $0.87(0.78-0.98)$ & - & $0.64(0.5 \mathrm{I}-0.80)$ \\
\hline Student & $1.07(0.7 \mathrm{I}-1.62)$ & $1.70(0.45-6.43)$ & - & $1.79(0.19-16.70)$ \\
\hline Other & $1.21(0.67-2.18)$ & $1.02(0.73-1.43)$ & - & $1.10(0.57-2.14)$ \\
\hline \multicolumn{5}{|l|}{ Self-perceived health } \\
\hline Optimal & 1 & 1 & 1 & 1 \\
\hline Suboptimal & I.0I $(0.85-1.20)$ & $0.82(0.74-0.92)$ & $1.26(0.94-1.70)$ & $0.81(0.68-0.96)$ \\
\hline \multicolumn{5}{|l|}{ Comorbidity* } \\
\hline No & 1 & 1 & 1 & 1 \\
\hline Yes & $1.14(0.99-1.32)$ & $0.99(0.86-1.14)$ & $0.94(0.78-1.12)$ & $1.03(0.8 \mathrm{I}-1.3 \mathrm{I})$ \\
\hline \multicolumn{5}{|l|}{$\begin{array}{l}\text { Smoking-related } \\
\text { diseases** }\end{array}$} \\
\hline No & 1 & 1 & 1 & 1 \\
\hline Yes & $1.17(1.02-1.33)$ & $1.04(0.94-1.15)$ & $0.95(0.8 \mathrm{I}-\mathrm{I} .12)$ & $1.13(0.95-1.35)$ \\
\hline \multicolumn{5}{|l|}{$\begin{array}{l}\text { Occupational physical } \\
\text { activity }\end{array}$} \\
\hline Inactive & 1 & 1 & 1 & 1 \\
\hline Light & $0.98(0.77-1.24)$ & $1.06(0.79-1.40)$ & $0.78(0.58-1.06)$ & $1.06(0.70-1.60)$ \\
\hline Moderate & $1.04(0.88-1.23)$ & $0.99(0.85-1.15)$ & $0.82(0.66-1.03)$ & $1.03(0.8 \mathrm{I}-1.30)$ \\
\hline Intense & $0.82(0.60-1.12)$ & $0.82(0.47-1.42)$ & $0.91(0.59-1.39)$ & $0.92(0.45-1.88)$ \\
\hline \multicolumn{5}{|c|}{ Leisure physical activity } \\
\hline Sedentary & 1 & 1 & 1 & 1 \\
\hline Moderate & $1.12(0.86-1.45)$ & $1.05(0.80-1.38)$ & $0.67(0.44-1.02)$ & $0.96(0.64-1.43)$ \\
\hline Intense & $0.95(0.73-1.23)$ & $1.03(0.99-1.07)$ & $0.69(0.38-1.26)$ & $0.83(0.49-1.39)$ \\
\hline \multicolumn{5}{|l|}{ Smoking habit } \\
\hline Never smoker & 1 & 1 & 1 & 1 \\
\hline Occasional smoker & $0.82(0.59-1.15)$ & $1.58(0.76-3.27)$ & $0.72(0.47-1.10)$ & $1.05(0.44-2.46)$ \\
\hline Former smoker & $1.10(0.91-1.33)$ & $1.12(0.84-1.47)$ & $1.12(0.87-1.43)$ & $1.16(0.78-1.74)$ \\
\hline \multicolumn{5}{|l|}{ Alcohol intake*** } \\
\hline Non-drinker & 1 & 1 & 1 & 1 \\
\hline Low risk & $0.99(0.81-1.19)$ & $1.27(1.03-1.56)$ & $1.38(1.07-1.80)$ & $1.35(0.96-1.91)$ \\
\hline Moderate risk & $0.93(0.76-1.14)$ & $1.62(1.23-2.13)$ & $1.05(0.85-1.29)$ & $1.23(0.83-1.81)$ \\
\hline High risk & $1.10(0.89-1.37)$ & $1.35(1.12-1.63)$ & $1.32(0.99-1.75)$ & $1.41(1.03-1.93)$ \\
\hline
\end{tabular}

\footnotetext{
*Absence or presence of chronic diseases

**Absence or presence of smoking-related disease (heart diseases, high blood pressure, varicose veins, asthma or chronic bronchitis, stomach or duodenal ulcer and cerebrovascular disease).

***Non-drinkers ( $0 \mathrm{~g} /$ day $)$, low risk $(<2.75 \mathrm{~g} /$ day $)$, moderate risk $(2.75-8.06 \mathrm{~g} /$ day $)$ and high risk $(>8.06 \mathrm{~g} /$ day $)$
} 
Table 3: Adjusted prevalence rate ratios (PR)* and $95 \%$ confidence intervals $(\mathrm{Cl})$ of exposure to second-hand smoke in different settings according socio-demographic variables in men. Cornellà, Spain, 2002.

\begin{tabular}{|c|c|c|c|c|}
\hline & Home PR $(95 \% \mathrm{Cl})$ & Leisure time PR $(95 \% \mathrm{Cl})$ & Workplace PR $(95 \% \mathrm{Cl})$ & Overall PR $(95 \% \mathrm{Cl})$ \\
\hline \multicolumn{5}{|l|}{ Marital status } \\
\hline Single & - & 1 & - & 1 \\
\hline Married & - & $0.46(0.31-0.68)$ & - & $0.5 \mathrm{I}(0.29-0.90)$ \\
\hline Widowed/Divorced & - & $0.62(0.37-1.05)$ & - & $0.58(0.31-1.07)$ \\
\hline \multicolumn{5}{|c|}{ Occupational physical activity } \\
\hline Inactive & 1 & - & 1 & - \\
\hline Light & $1.17(0.94-1.47)$ & - & $1.47(1.05-2.07)$ & - \\
\hline Moderate & $1.06(0.94-1.19)$ & - & $1.08(0.88-1.33)$ & - \\
\hline Intense & $1.35(1.05-1.74)$ & - & $1.45(1.04-2.01)$ & - \\
\hline \multicolumn{5}{|l|}{ Smoking habit } \\
\hline Never smoker & - & - & - & I \\
\hline Occasional smoker & - & - & - & $3.47(1.15-10.44)$ \\
\hline Former smoker & - & - & - & $0.89(0.67-1.18)$ \\
\hline \multicolumn{5}{|l|}{ Alcohol intake $* *$} \\
\hline Non-drinker & - & 1 & - & - \\
\hline Low risk & - & $1.21(0.86-1.69)$ & - & - \\
\hline Moderate risk & - & $1.26(0.99-1.62)$ & - & - \\
\hline High risk & - & $1.40(1.09-1.81)$ & - & - \\
\hline
\end{tabular}

*Adjusted for age and the rest of the variables in the table.

**Non-drinkers ( $0 \mathrm{~g} /$ day), low risk $(<6.87 \mathrm{~g} /$ day $)$, moderate risk $(6.87-17.75 \mathrm{~g} / \mathrm{day})$ and high risk $(>17.75 \mathrm{~g} / \mathrm{day})$

ees in the hospitality sector. These workers had worse respiratory health and were more exposed to SHS than participants who lived with a smoker [45], and levels of SHS in restaurants were twofold those in office workplaces where smoking was allowed $[37,46,47]$. However, the recent introduction of anti-smoking laws has led to a reduction in exposure to SHS in hospitality workers [4854].

The limitations of this study derive from the fact that cross-sectional data based on information gathered by questionnaire are potentially subject to some degree of systematic error. The method used here to measure SHS exposure has not been formally validated. The questions used in the survey are partially derived from those used in other studies[16], although we added new items designed to enquire about exposure during leisure time [24]. Additional studies on SHS exposure should consider the use of biological markers of passive exposure [55-57]. These limitations notwithstanding, the measurement of "perceived" SHS exposure with a set of simple questions may provide sufficiently valid estimates in the absence of expensive biomarker data [58-62].

Some selection bias was possible because the sample studied was not completely representative of the Cornellà population. The sample we analysed is missing a portion of young and old participants of both sexes, mainly due to attrition attributable to deaths and emigration [22]. Thus, the prevalence of general exposure to SHS might be still higher; since young people (under-represented in the sample) are those who are most exposed.

The estimates of SHS exposure discussed here did not consider duration of exposure, except for leisure time exposure. Although the prevalence of SHS exposure during leisure time is important, its duration is shorter than SHS exposure at home or at the workplace. Unfortunately, we did not collect information on the proportion of time spent in each setting. Doing so would have helped to better understand the contribution of each setting to overall exposure and related risk. Future studies should consider the contribution of each setting to overall exposure and the dose of exposure in more detail, to better quantify the hazard that SHS exposure represents. A final consideration is that we assessed "current" self-reported exposure to SHS, whereas other studies have analysed cumulative lifetime exposure, which is relevant for etiologic studies [6366].

\section{Conclusion}

The prevalence of self-reported SHS exposure in this Mediterranean population was very high, and correlated mainly with age and occupational status in men, and with age and educational level in women. These findings highlight the need to curtail the smoking epidemic and limit second-hand smoke exposure in Spain. The Spanish law banning smoking in all enclosed workplaces and public places (with certain exceptions for bars and restaurants) is a necessary but insufficient stimulus to achieve smokefree environments [20,67]. 
Table 4: Adjusted prevalence rate ratios (PR)* and $95 \%$ confidence intervals $(\mathrm{Cl})$ of exposure to second-hand smoke in different settings according socio-demographic variables in women. Cornellà, Spain, 2002.

\begin{tabular}{|c|c|c|c|c|}
\hline & Home PR $(95 \% \mathrm{Cl})$ & Leisure time PR $(95 \% \mathrm{Cl})$ & Workplace PR $(95 \% \mathrm{Cl})$ & Overall PR $(95 \% \mathrm{Cl})$ \\
\hline \multicolumn{5}{|l|}{ Educational level } \\
\hline \multicolumn{5}{|l|}{$\leq$ Primary studies } \\
\hline Secondary studies & - & $1.15(0.74-1.79)$ & $1.16(0.93-1.45)$ & $0.73(0.4|-| .3 I)$ \\
\hline University studies & - & $1.65(0.83-3.29)$ & $1.47(1.05-2.07)$ & $3.80(0.95-15.16)$ \\
\hline \multicolumn{5}{|l|}{ Marital status } \\
\hline Single & - & 1 & - & I \\
\hline Married & - & $0.59(0.44-0.78)$ & - & $0.77(0.50-1.21)$ \\
\hline Widowed/Divorced & - & $0.75(0.59-0.95)$ & - & $0.67(0.47-0.96)$ \\
\hline \multicolumn{5}{|l|}{ Occupational status } \\
\hline Employed & 1 & 1 & - & 1 \\
\hline Unemployed & $0.98(0.68-\mid .4 I)$ & $1.13(0.62-2.09)$ & - & $1.05(0.4 \mathrm{I}-2.72)$ \\
\hline Disabled & $0.92(0.55-1.56)$ & $0.76(0.51-1.12)$ & - & $0.61(0.32-1.15)$ \\
\hline Retired & $0.98(0.78-1.24)$ & $1.03(0.91-1.16)$ & - & $0.88(0.68-1.14)$ \\
\hline Housewife & $0.85(0.72-1.00)$ & $0.96(0.86-1.06)$ & - & $0.65(0.5 \mathrm{I}-0.82)$ \\
\hline Student & $1.12(0.75-1.69)$ & $1.17(0.25-5.40)$ & - & $1.95(0.19-19.64)$ \\
\hline Other & $1.18(0.64-2.16)$ & $1.12(0.86-1.46)$ & - & $1.33(0.74-2.40)$ \\
\hline \multicolumn{5}{|l|}{ Self-perceived health } \\
\hline Optimal & - & I & - & 1 \\
\hline Suboptimal & - & $0.87(0.78-0.96)$ & - & $0.86(0.72-1.02)$ \\
\hline \multicolumn{5}{|l|}{$\begin{array}{l}\text { Smoking-related } \\
\text { diseases } * *\end{array}$} \\
\hline No & 1 & - & - & - \\
\hline Yes & $1.16(1.02-1.33)$ & - & - & - \\
\hline \multicolumn{5}{|l|}{ Alcohol intake ${ }^{* * * *}$} \\
\hline Non-drinker & - & I & I & 1 \\
\hline Low risk & - & $1.21(0.96-1.52)$ & $1.38(1.05-1.81)$ & $1.25(0.87-1.91)$ \\
\hline Moderate risk & - & $1.58(1.17-2.13)$ & $1.02(0.82-1.28)$ & $1.07(0.69-1.65)$ \\
\hline High risk & - & $1.30(1.05-1.61)$ & $1.26(0.93-1.72)$ & $1.34(0.95-1.89)$ \\
\hline
\end{tabular}

*Adjusted for age and the rest of the variables in the table.

**Absence or presence of smoking-related disease (heart diseases, high blood pressure, varicose veins, asthma or chronic bronchitis, stomach or duodenal ulcer and cerebrovascular disease).

***Non-drinkers ( $0 \mathrm{~g} /$ day $)$, low risk $(<2.75 \mathrm{~g} /$ day $)$, moderate risk $(2.75-8.06 \mathrm{~g} /$ day $)$ and high risk $(>8.06 \mathrm{~g} /$ day $)$

\section{Abbreviations}

SHS: second-hand smoke; CHIS.FU: Cornellà Health Interview Survey Follow-up; CI: confidence interval; PR: prevalence rate ratio.

\section{Competing interests}

The author(s) declare that they have no competing interests.

\section{Authors' contributions}

$\mathrm{EF}, \mathrm{AS}, \mathrm{MG}$, and JMB designed the study protocol. AS and MG co-ordinated the follow-up data collection. JT, AS and EF designed the study on second-hand smoke. JT checked the information referring to second-hand smoke. JT, AS and EF developed the strategy for analysis, JT performed the statistical analysis, and all the authors contributed to the interpretation of the results. JT wrote the first draft of the manuscript, to which all the authors made contributions. $\mathrm{EF}$ is the guarantor of the paper.

\section{Appendix. Details on questionnaire wording and construction of variables Exposure at home}

The questions was, "Do any members of your family usually smoke at home?"

\section{Exposure during leisure time}

The question was, "On average, how long are you exposed to tobacco smoke outside your home and at your workplace per day on Monday to Thursday or Wednesday to Sunday?" Duration of exposure was recorded on an ordinal scale as $0,<1$ hour, $1-4$ hours, and $>4$ hours);

\section{Exposure at the workplace}

The question was, "Do any people smoke near you at the workplace?"

\section{Exposure at any of the settings (overall second-hand smoke exposure)}

Participants who responded that they were not exposed at home, during leisure time or at the workplace were con- 
sidered "not exposed overall to SHS". Participants who responded affirmatively to any of the questions were considered "exposed overall to SHS".

\section{Acknowledgements}

This study was partially funded by the Fondo de Investigación Sanitaria (PI02026I and PI02098I), Instituto de Salud Carlos III (Research Network in Epidemiology and Public Health, RCESP C03/09, and in Research Network in Cancer, RTICC C03/I0, RD06/0020/0089), and the Department of Universities and Research, Government of Catalonia (2003XT/00090 and AGAUR 00646). We thank Prof. A. Muñoz for providing the S-Plus functions to plot the equiponderant graphics, and K. Shashok for improving the use of English in the manuscript.

The Cornella Health Interview Survey Follow-up Study Group: Carme Borrell, Josep Maria Borràs, Montse Garcia, Mercè Martí, F. Javier Nieto, Esteve Saltó, Anna Schiaffino, Glòria Pérez, Mercè Peris, Jorge Twose, and Esteve Fernández (Principal Investigator).

\section{References}

I. U.S Department of Health and Human Services (DHHS): The health consequences of involuntary smoking. A report of the Surgeon General. Department of Health and Human Services publication. Bethesda: Centers for Disease Control, publication 878398; 1986.

2. US Environmental Protection Agency: Respiratory health effects of passive smoking: lung cancer and other disorders. EPA/ 600/006F. Washington: US Environmental Protection Agency; 1992.

3. Tobacco smoke and involuntary smoking. In IARC Monographs Volume 83. Lyon: International Agency for Research on Cancer; 2004.

4. U.S Department of Health and Human Services (DHHS): 2006 Surgeon General's Report - The Health Consequences of Involuntary Exposure to Tobacco Smoke. Department of Health and Human Services publication 1986 [http://www.cdc.gov/tobaccol data statistics/sgr/sgr 2006/index.htm]. Bethesda: Centers for Disease Control [accessed: May 20, 20067]

5. Schiaffino A, Fernández E, Borrell C, Garcia M, Salto E, Borras JM: Gender and educational differences in smoking initiation rates in Spain from 1948 to 1992. Eur J Public Health 2003, 13:56-60.

6. Fernández E, Schiaffino A, Garcia M, Borras JM: Widening social inequalities in smoking cessation in Spain, 1987-1997. J Epidemiol Community Health 200I, 55:729-30.

7. Fernandez E, Schiaffino A, Borras JM, Shafey O, Villalbi JR, La Vecchia $\mathrm{C}$ : Prevalence of cigarette smoking by birth cohort among males and females in Spain, 1910-1990. Eur J Cancer Prev 2003, 1 2:57-62.

8. Shafey O, Fernández E, Thun M, Schiaffino A, Dolwick S, Cokkinides $V$ : Case studies in international tobacco surveillance: Cigarette advertising and female smoking prevalence in Spain, 1982-1997. Cancer 2004, 100:1744-1749.

9. Schiaffino A, Fernandez E, Kunst A, Borrell C, Garcia M, Borras JM, Mackenbach JP: Time trends and educational differences in the incidence of quitting smoking in Spain (1965-2000). Prev Med 2007 in press.

10. Lopez MJ, Nebot M: Tabaquismo pasivo: un riesgo ignorado. Med Clin (Barc) 2004, I 23:503-4.

II. Fernández E, Schiaffino A, García M, Twose J: Efectos del humo ambiental de tabaco sobre la salud : revisión de la evidencia científica. In Espacios laborales libres de humo Edited by: Baroja Benlliure J, Salvador Llivina T, Córdoba García R, Villalbí Hereter JR. Madrid: Comité Nacional para la Prevención del Tabaquismo y Ministerio de Sanidad y Consumo; 2006:15-30.

12. Bonfill X, Serra C, Lopez V: Employee and public responses to simulated violations of no-smoking regulations in Spain. Am J Public Health 1997, 87: 1035-7.

13. Serra Pujadas C, Bonfill Cosp X, Lopez Clemente V: Consumo y venta de tabaco en lugares públicos: evaluación del cumplimiento de la normativa vigente. Gac Sanit 1997, I I:55-65.
14. Cordovilla R, Barrueco M, Gonzalez Ruiz JM, Hernandez MA, de Castro J, Gomez F: Cumplimiento de la legislación antitabaco en instituciones oficiales. Arch Bronconeumol 1997, 33:320-4.

15. Janson C, Chinn S, Jarvis D, Zock J-P, Torén K, Burney P, for the European Community Respiratory Health Survey: Effect of passive smoking on respiratory symptoms, bronchial responsiveness, lung function, and total serum IgE in the European Community Respiratory Health Survey: a cross-sectional study. Lancet 200I, 358:2 103-9.

16. Nebot M, López MJ, Tomás Z, Ariza C, Borrell C, Villalbí JR: Exposure to environmental tobacco smoke at work and at home: a population based survey [letter]. Tob Control 2004, 1 3:95.

17. Twose J, Schiaffino A, García M, Martí M, Fernández E, Investigadores del Estudio de Seguimiento de la Encuesta de Salud de Cornellà: Prevalencia de la exposición al humo ambiental del tabaco en Cornellà de Llobregat. Medicina Clínica (Barcelona) 2004, I 23:496-8.

18. Jane M, Nebot M, Rojano X, Artazcoz L, Sunyer J, Fernandez E, et al:: Exposure to environmental tobacco smoke in public places in Barcelona, Spain [letter]. Tob Control 2002, I I:83-4.

19. Ley $\mathbf{2 8} / 2005$, de $\mathbf{2 6}$ de diciembre, de medidas sanitarias frente al tabaquismo y reguladora de la venta, el suministro, el consumo y la publicidad de los productos del tabaco (ley 28/2005 de 26 de diciembre de 2005 Madrid: Boletín Oficial del Estado 2005 [http://www.msc.es/ciudadanos/proteccionSalud/adoles cencia/docs/Ley28 2005.pdf]. [accessed May 24, 2007]

20. Fernandez E: Spain: going smoke free. Tob Control 2006, 15:79-80.

21. Garcia M, Schiaffino A, Fernandez E, et al:: The Cornellà Health Interview Survey Follow-up (CHIS.FU) Study: design, methods, and response rate. BMC Public Health 2003, 3:12.

22. Garcia M, Fernandez E, Schiaffino A, Borrell C, Marti M, Borras JM Attrition in a population-based cohort 8 years after baseline interview. The Cornella Health Interview Survey Follow-up (CHIS.FU) Study. Ann Epidemiol 2005, 1 5:98-104.

23. Departament de Salut Pública: Ajuntament de Cornellà. Enquesta de Salut. Cornellà de Llobregat, 1993-1994. Cornellà de Llobregat: Ajuntament de Cornellà de Llobregat 1995.

24. Garcia M, Fernandez E, Schiaffino A, Peris M, Borras JM, Nieto FJ: Phone tracking in a follow-up study. Soz Praventivmed 2005, 50:63-6.

25. Martín A, Schiaffino A, Twose J, Pacual JA, Nebot M, Saltó E, Moncada A, Fu M, Fernández E: Exposición al humo ambiental del tabaco en la población no fumadora de Barcelona. Gac Sanit 2006, 20(supl 3): 13 .

26. Welsh Heart Health Survey 1985: protocol and questionnaire. Wales: Health Promotion Authority for Wales; (Technical report No. 2) 1989

27. Domínguez-Berjón MF, Borrell C, Nebot M, Artazcoz L, Moncada S, Plasencia A: Actividad física habitual de la población residente en la ciudad de Barcelona. Gac Sanit 1998, I 2: 1 10-7.

28. Li X, Buechner JM, Tarwater PM, Muñoz A: A diamond-shaped equiponderant graphical display of the effect of two categorical predictors on continuous outcomes. Am Stat 2003, 57:193-9.

29. Schiaffino A, Rodríguez MC, Pasarín MI, Regidor E, Borrell C, Fernández E: ¿Odds ratio o razón de proporciones?. Su utilización en estudios transversales. Gac Sanit 2003, 17:70-4.

30. Stromberg U: Prevalence odds ratio v prevalence ratio -some further comments. Occup Environ Med 1995, 52: | 43.

31. Osborn J, Cataruzza MS: Odds ratio and relative risk for crosssectional data. Int I Epidemiol 1995, 24:464-5.

32. Nebot M, Lopez MJ, Gorim G, et al: Environmental tobacco smoke exposure in a sample of European cities. Tob Control 2005, 14:60-3.

33. Pérez-Ríos M, Santiago-Pérez MI, Alonso B, Malvar A: Exposure to secondhand smoke at home, work and in public place: $A$ population based survey in Spain before to an anti-smoking law implementation. Eur Resp J 2007, 29:8I8-9.

34. Galán I, Mata N, Guirao A, Velázquez L, Estrada C, Díez L, et al.: Efecto de la "ley del tabaco" sobre el consumo y la expsición ambiental a humo de tabaco. Gac Sanit 2006, 20(supl 3): 129.

35. Mannino M, Siegel M, Rose D, Nkuchia J, Etzel R: Environmental tobacco smoke exposure in the home and worksite and health effects in adults: results from the 1991 National Health Interview Survey. Tob Control 1997, 6:296-305. 
36. National Center for Health Statistics: Health, United States, 2003 with chartbook on trends in the health of Americans. Hyattsville, MD 2003:212 [http://www.cdc.gov/nchs/hus.htm]. [accessed 20/ 09/04]

37. López MJ, Nebot M, Sallés J, Serrahima E, Centrich F, Juárez O, Ariza C: Medición de la exposición al humo ambiental de tabaco en centros de enseñanza, centros sanitarios, medios de transporte y lugares de ocio. Gac Sanit 2004, I 8:45I-7.

38. Regidor E, Gutierrez-Fisac JL, Calle ME, Navarro P, Dominguez V Trends in cigarette smoking in Spain by social class. Prev Med 200I, 33:241-8.

39. Artazcoz L, Brotons M, Brotons A: Impacto de la implantación de una política de trabajo libre de humo en una empresa. Gac Sanit 2003, 17:490-3.

40. Garcia de Albeniz XA, Guerra-Gutierrez F, Ortega-Martinez R Sanchez-Villegas A, Martinez-Gonzalez MA: Consumo de tabaco en titulados universitarios. El proyecto SUN (Seguimiento Universidad de Navarra). Gac Sanit 2004, I 8: I08-I7.

4I. Cano-Serral G, Rodriguez-Sanz M, Borrell C, Perez Mdel M, Salvador J: Desigualdades socioeconomicas relacionadas con el cuidado y el control del embarazo. Gac Sanit 2006, 20:25-30.

42. Perez-Rios M, Santiago-Perez MI, Alonso B: Abandono del consumo de tabaco en las fumadoras gallegas durante e embarazo o la lactancia, 1954-2004. Gac Sanit 2006, 20:392-5.

43. Whitlock G, MacMahon S, Vander Hoorn S, Davis P, Jackson R, Norton R: Association of environmental tobacco smoke exposure with socioeconomic status in a population of 7725 New Zealanders. Tob Control 1998, 7:276-80.

44. Veglia F, Vineis P, Berrino F, Cerulli Ddel S, Giurdanella MC, Tumino R, Fiorini L, Sacerdote C, Panico S, Mattiello A, Palli D, Saieva C, Davico L: Determinants of exposure to environmental tobacco smoke in 21,588 Italian non-smokers. Tumori 2003, 89:665-8.

45. Dimich-Ward H, Lawson J, Hingston A, Chan-Yeung M: Impact of smoking policy on the respiratory health of food and beverage servers. Scand J Work Environ Health 2005, 3 I:75-8I.

46. Siegel $\mathrm{M}$ : Involuntary smoking in the restaurant workplace. A review of employee exposure and health effects. JAMA 1993, 270:490-3.

47. Hammond SK: Exposure of U.S. workers to environmental tobacco smoke. Environ Health Perspect 1999, I07(Supl.2):329-40.

48. Farrelly MC, Nonnemaker JM, Chou R, Hyland A, Peterson KK, Bauer UE: Changes in hospitality workers' exposure to secondhand smoke following the implementation of New York's smokefree law. Tob Control 2005, I 4(4):236-4I.

49. Allwright S, Paul G, Greiner B, Mullally BJ, Pursell L, Kelly A, et al: Legislation for smoke-free workplaces and health of bar workers in Ireland : before and after study. BMJ 2005 33 I(7525): I | |7-23.

50. Gorini G, Gasparrini A, Fondelli MC, Costantini AS, Centrich F, Lopez MJ, Nebot M, Tamang E: Environmental tobacco smoke (ets) exposure in Florence hospitality venues before and after the smoking ban in Italy. J Occup Environ Med 2005, 47(I 2): I208-I0.

5I. Skogstad M, Kjaerheim K, Fladseth G, Gjolstad M, Daae HL, Olsen R, Molander P, Ellingsen DG: Cross shift changes in lung function among bar and restaurant workers before and alter implementation of a smoking ban. Occup Environ Med 2006, 63:482-7.

52. Menzies D, Nair A, Williamson PA, Schembri S, Al-Khairalla MZ, Barnes M, Fardon TC, McFarlane L, Magee G], Lipworth BJ: Respiratory symptoms, pulmonary function, and markers of inflammation among bar workers before and after a legislative ban on smoking in public laces. JAMA 2006, 296: I 742-8.

53. Johnsson T, Tuomi T, Riuttala H, Hyvarinen M, Rothberg M, Reijula K: Environmental tobacco smoke in Finnish restaurants and bars before and after smoking restrictions were introduced. Ann Occup Hyg 2006, 50:33I-4I.

54. Wilson N, Edwards R, Maher A, Nathe J, Jalali R: National smokefree law in New Zealand improves air quality inside bars, pubs and restaurants. BMC Public Health 2007, 7:85.

55. López MJ, Nebot M: La medición de la nicotina como marcador aéreo del humo ambiental del tabaco (HAT). Gac Sanit 2003 I 7(Supl.3): |6-2|.

56. Benowitz NL: Biomarkers of environmental tobacco smoke exposure. Environ Health Perspect 1999, 10:349-55

57. Seccareccia F, Zuccaro P, Pacifici R, Meli P, Pannozzo F, Freeman KM, et al: Serum cotinine as a marker of environmental tobacco smoke exposure in epidemiological studies: The experience of the MATISS project. Eur J Epidemiol 2003, I 8:487-92.

58. Jaakkola MS, Jaakkola J]: Assessment of exposure to environmental tobacco smoke. Eur Respir J 1997, 10:2384-97.

59. Nondahl DM, Cruickshanks KJ, Schubert CR: A questionnaire for assessing environmental tobacco smoke exposure. Environ Res 2005, 97:76-82

60. Pirkle JL, Flegal KM, Bernert JT, Brody DJ, Etzel RA, Maurer KR: Exposure of the US population to environmental tobacco smoke. The Third National Health and Nutrition Examination Survey, I988 to I99 I. JAMA 1996, 275:I233-40.

6I. Olivieri M, Poli A, Zuccaro P, Ferrari M, Lampronti G, de Marco R, Lo Cascio V, Pacifici R: Tobacco smoke exposure and serum cotinine in a random sample of adults living in Verona, Italy. Arch Environ Health 2002, 57:355-9.

62. Riboli E, Preston-Martin S, Saracci R, Haley NJ, Trichopoulos D, Becher $\mathrm{H}$, et al:: Exposure of nonsmoking women to environmental tobacco smoke: a I0-country collaborative study. Cancer Causes Control 1990, I:243-52.

63. Curtin F, Morabia A, Bernstein M: Lifetime exposure to environmental tobacco smoke among urban women: differences by socioeconomic class. Am J Epidemiol 1998, I 48: I040-7.

64. Vineis $\mathrm{P}$, Airoldi L, Veglia $\mathrm{P}$, Olgiati L, Pastorelli R, Autrup $\mathrm{H}$, et al: Environmental tobacco smoke and risk of respiratory cancer and chronic obstructive pulmonary disease in former smokers and never smokers in the EPIC prospective study. BM] 2005, 330:277.

65. Boffetta P, Agudo A, Ahrens W, Benhamou E, Benhamou S, Darby SC, et al.: Multicenter case-control study of exposure to environmental tobacco smoke and lung cancer in Europe. J Natl Cancer Inst 1998, 90: |440-50.

66. Cummings KM, Markello SJ, Mahoney MC, Marshall JR: Measurement of lifetime exposure to passive smoke. Am J Epidemio 1989, 130:122-32.

67. Villalbi JR: De las propuestas del movimiento de prevención al consenso político: la ley de medidas sanitarias contra el tabaquismo. Gac Sanit 2006, 20:1-3.

\section{Pre-publication history}

The pre-publication history for this paper can be accessed here:

\section{http://www.biomedcentral.com/1471-2458/7/194/pre}

pub

Publish with Biomed Central and every scientist can read your work free of charge

"BioMed Central will be the most significant development for disseminating the results of biomedical research in our lifetime. "

Sir Paul Nurse, Cancer Research UK

Your research papers will be:

- available free of charge to the entire biomedical community

- peer reviewed and published immediately upon acceptance

- cited in PubMed and archived on PubMed Central

- yours - you keep the copyright 